\title{
Green Economy in Russia: Leadership and Financial Aspects
}

\author{
Elena Tarkhanova \\ University of Tyumen \\ Volodarskogo Street 6, 625003 Tyumen \\ Russian Federation \\ e-mail: tarhanova333@mail.ru \\ Anhelica Fricler \\ University of Tyumen \\ Volodarskogo Street 6, 625003 Tyumen \\ Russian Federation \\ e-mail: abyscheva@mail.ru \\ Natalia Baburina \\ University of Tyumen \\ Volodarskogo Street 6, 625003 Tyumen \\ Russian Federation \\ e-mail: natalbaburina@mail.ru
}

\begin{abstract}
Nowadays, European countries pursue an active policy in the field of greening the economy, expanding the practice known as "green finances". The main goal of this activity is, above all, in the achievement of environmentally sustainable economic growth.

However, it has to be noted that in the Russian Federation the movement towards greening the economy began later than in other countries. Therefore, specific measures and mechanisms are required to implement the concept of transition from a brown economy to a green one. In order to modernize the Russian economy, financial resources are needed, including those originating in the private sector.

All in all, it becomes appropriate to consider the composition of financial instruments for green financing, in which temporarily available cash is allocated in such a way that as a result a synergy of economic effect and environmental benefit is achieved. Our paper focuses on these problematic economic issues concerning leadership in the green economy of Russia and the development of green financing as the basis for environmentally sustainable evolution.
\end{abstract}

\section{Introduction}

Human activities are inextricably linked to the environment. In the early stages of human society, man was fully dependent on nature. However, scientific and technological progress has allowed humanity to withdraw resources from nature and transform them to meet the diverse needs of society (Cieslik et al. 2016). This circumstance led to an increase in the anthropogenic load on the ecosystem and a violation of the general ecological balance, therefore there was an urgent need to form a new outlook on nature and the economy. This type of environmentally friendly economy has come to be called the "green" economy (Tarkhanova 2018; Lisin et al. 2018; Hoop and Tarkhanova 2019).

The term "green economy" was first used by an environmental economist from Great Britain in 1989 when his book "Blueprint for a Green Economy, Earthscan Publications Limited" was published. For the first time, Pearce presented practical policies for greening modern economies and their path to sustainable development (Pearce 2019). However, this book did not contain a definition of the term "green" economy.

Todaya, the most authoritative definition of a green economy is the definition formulated by the United Nations Environment Program (UNEP), according to which a green economy is an economy that provides "longterm improvement of human well-being and reduction of inequality, allowing future generations to avoid significant environmental risks. environment and its impoverishment" (United Nations 2019).

The development of a green economy as a concept of sustainable development began in 1972 when the United Nations Environment Program (UNEP) was adopted at the UN Conference in Stockholm, which contained a model that would create a society that could meet the needs of today's generations, while saving resources for future (UNCTAD 2019). This event meant the readiness of the world community at the highest level to solve environmental problems. 
It is important to note that for each country, the transition to a green economy is characterized by specific features that are determined by the characteristics of natural and human capital, as well as the level of development of the country.

The transition to a green economy allows countries to obtain certain social and economic benefits, as well as ensure sustainable development of the country. Currently, many countries are leading the way in applying the concept of a green economy, using the following measures:

- $\quad$ an increase in investment in the sectors of the green economy;

- raising awareness of the opportunities and benefits of a green economy for the population and business;

- willingness to help and develop networks of special organizations and institutions that ensure the transition to a new model of the economy;

- the use of taxation as a tool to minimize the negative impact on nature;

- the development of international cooperation with the goal of overall sustainable development.

\section{Green financing tools}

Without a doubt, the implementation of green transformations requires several important components. Firstly, sufficient funding is needed, both from the state and from the private sector. Secondly, a system of instruments of "green" financing is needed, which would allow redistributing temporarily free cash from the sectors of the brown economy to the sector of the green economy. Thirdly, the process of transition to a new type of economy is possible only with active state support, both from the creation of the necessary regulatory framework, and from the optimization of costs that stimulate the green economy.

These areas should be implemented as part of green projects. Considering the creation of such projects in terms of supply and demand, we can divide all the players into two groups: state institutions and private organizations (Lisin et al. 2015). All of them can stimulate the development of the green finance market through available financial resources and authorities. A green project can be initiated by government agencies, private companies and organizations, or individuals.

The Bank of Russia Long-term Investment Market Expert Council Highlights the Following Green Finance Market Participants (Central Bank of Russia 2018):

1. National development institutions:

1.1. Vnesheconombank participating in the implementation of projects on the principles of public-private partnership and municipal-private partnership.

1.2. The Russian Industrial Development Fund, the main purpose of which is lending to the development of new high-tech products, technical re-equipment and the creation of competitive industries based on the best technologies.

1.3. The Fund for Assistance to the Reform of Housing and Communal Services, which provides financial support to the constituent entities of the Russian Federation and municipalities for the overhaul of apartment buildings and the relocation of citizens from emergency housing.

2. Commercial banks and insurance organizations:

2.1. Sberbank of Russia, which as a pilot project proposes to consider "green" bonds issued by issuers to finance projects that fall into the category of "green".

3. Issuers of green bonds. These include companies and organizations of various sectors of the economy that identify themselves as participants in the "green" market.

4. The Moscow Exchange, which has tools to promote a green financial system, allows green bonds to be traded and encourages issuers to increase transparency.

5. Institutes of examination and certification:

5.1. Interfax-ERA Environmental and Energy Rating Agency, created to analyze the environmental and energy efficiency of the economy.

5.2. The NRA Analytical Center, one of the activities of which is the compilation of environmental ratings: the environmental responsibility rating of Russian oil and gas companies, the social and environmental responsibility of Russian forest sector companies, and the environmental openness ratings of pulp and paper companies in the Russian forest sector.

5.3. The Association "National Environmental Audit Chamber", which is actively involved in the development of proposals for the development of legislation of the Russian Federation on environmental auditing, etc.

Resources for green projects can be provided by state corporations, financial sector companies, investors, as well as private companies using their own income. 
Among the main instruments of green financing, the World Bank allocates debt financing, equity financing and lending. Such "green" operations form an overflow of capital in environmental industries and projects (World Bank 2018).

As the main instrument of debt financing, green bonds are used. Today it is one of the most rapidly growing segments of the international securities market. Green bonds include not only securities issued as part of the implementation of a specific project, but also those obligations issued by subjects of green industries (for example, alternative energy) (see Shevchenko 2018). The London Stock Exchange defines green bonds as a special type of investment, as a result of which the received funding will be used exclusively to finance new and / or existing green projects (EBRD 2019). According to the World Bank, green bonds are leaders in financing environmental investments and have attracted significant attention as investors around the world. The issuer of such debt securities may be a corporation, a state or central government, a bank, a non-bank financial company or a research organization (World Bank 2018). The People's Bank of China for the first time issued green bonds at the national level in 2015, stimulating private investment to transition to a green economy" (Andreeva 2016).

Among equity financing instruments, "green" equity securities are key. This is equity used to finance green activities. Equity securities are divided into:

- Quoted shares of infrastructure and utilities, investment funds and other commercial entities;

- Shares of profitable companies (Nozdryva 2018).

Green lending is used by financial institutions to finance the production of environmentally friendly goods and services. For example, in the sectors of renewable energy, energy efficiency, waste management and others (French 2017). In Russia today, this type of lending is not a priority, since the environmental effect of such projects can not always be expressed economically, and the payback period of such projects is very long (Shevchenko 2018).

Scientific literature on the greening of the economy indicates that there are no universal financing tools for all greening projects in the economy. The choice of financing instruments depends on many factors: the size of the project, the development of the national investment sector and the availability of financial instruments, the economic situation, legal factors, etc. Any traditional financial instrument can be recognized as "green". The main thing is that attracted financing should be directed exclusively to the implementation of green projects and activities. In other words, the "greenness" of a financial instrument is acquired in the process of its use and depends on the objectives of the financed assets (Andreeva 2017).

Today, the world has a tendency that the responsibility for the conservation of biodiversity lies with economically developed countries. Therefore, it becomes logical that today this group of countries is actively launching "green" projects aimed at stabilizing and improving the environment, using various financial instruments. Despite the many measures taken today in Russia it was not possible to form a support system for green financing, since little attention is paid to methods of attracting private capital in green projects, which is the main source of financing for such projects (Rakov 2017).

\section{Overview of green finance and leadership position in Russia}

The analysis of the current state of the Russian green finance market is of interest to identify the main trends and problems in this area. The feasibility of launching the transition to a green economy is determined, first of all, by the alleged specificity of the impact of the green economy on economic growth. In addition, an important aspect is that this transition provides the opportunity to integrate not only environmental, but also social imperatives into the economy. However, modernization spurts require large financial costs, so the key obstacle to building an environmentally friendly economy is the lack of funding.

Turning to the experience of countries that have achieved significant success in the field of "greening" the economy, it can be noted that according to the results of 2017, environmental costs amounted to (Federal State Statistics Service 2019d): in Germany - $0.6 \%$ of GDP, in the Netherlands - $1.4 \%$ of GDP, in France - $1 \%$ of GDP, in Japan - 1.2\% of GDP. In Russia, the share of environmental protection costs has not changed since 2009 and amounts to $0.7 \%$ of GDP. According to some experts, in order for Russia to achieve significant success in creating a green finance system, at least $1.3 \%$ of GDP should be spent annually on this area (Panda 2017).

The need for a transition to a model of sustainable development has created a need for the formation of a system of indicators to assess the success of countries on this. One such indicator is the Green Global Economy Index (GGEI), which is calculated on the basis of quantitative and qualitative indicators. This indicator is designed to measure how well each country works in four key areas: leadership and climate change, efficiency sectors, markets and investments, and the environment. GGEI was the first green economy index launched in 2010 and today is the most widely used product of its kind internationally, used by politicians, international organizations, civil society and the private sector (Dual Citizen 2019). 
It is important to note that in 2010 the index was collected only for individual countries, but by 2018 the number of countries was 130 . The index for Russia was first calculated in 2016. In addition, it is important to note that in 2018, the final indicator was expressed as a percentage, representing the total result for 4 main measurements, and not in points, as it was before, therefore, it is not possible to analyze the changes in this indicator for different periods of time.

Based on the data in Table 1, which provides information on leaders (5 countries) and outsiders (5 countries), as well as the place of Russia, it can be concluded that the development of green financing is a modern global trend and the first places belong to those countries who pursue an active environmental policy at the national level and for which it is one of the priority areas. However, Russia today is still far from the leading countries and has a low GGEI, so there is a need to identify problems and barriers that impede this development.

Table 1. Green Global Economy Index in 2018

\begin{tabular}{|l|c|c|}
\hline \multicolumn{1}{|c|}{ Country } & Ranking & GGEI Value \\
\hline Sweden & 1 & 0,7608 \\
\hline Switzerland & 2 & 0,7594 \\
\hline Iceland & 3 & 0,7129 \\
\hline Norway & 4 & 0,7031 \\
\hline Finland & 5 & 0,6997 \\
\hline$\ldots$ & $\ldots$ & $\ldots$ \\
\hline Russian Federation & 105 & 0,4115 \\
\hline$\ldots$ & $\ldots$ & $\ldots$ \\
\hline Guinea Bissau & 125 & 0,3510 \\
\hline Bosnia and Hercegovina & 127 & 0,3441 \\
\hline Benin & 128 & 0,3434 \\
\hline Haiti & 129 & 0,3390 \\
\hline Bahrain & 130 & 0,3304 \\
\hline
\end{tabular}

Source: Own results based on Dual Citizen (2019)

Based on the data in Figure 1, the analyzed period (2009-2018) can be described as a period of growth of green investments in Russia. For the period 2008-2018 the growth rate of green investments in the Russian Federation amounted to $53.97 \%$, while the growth rate of investments in fixed assets amounted to $100.36 \%$ (Federal State Statistics Service 2019a)

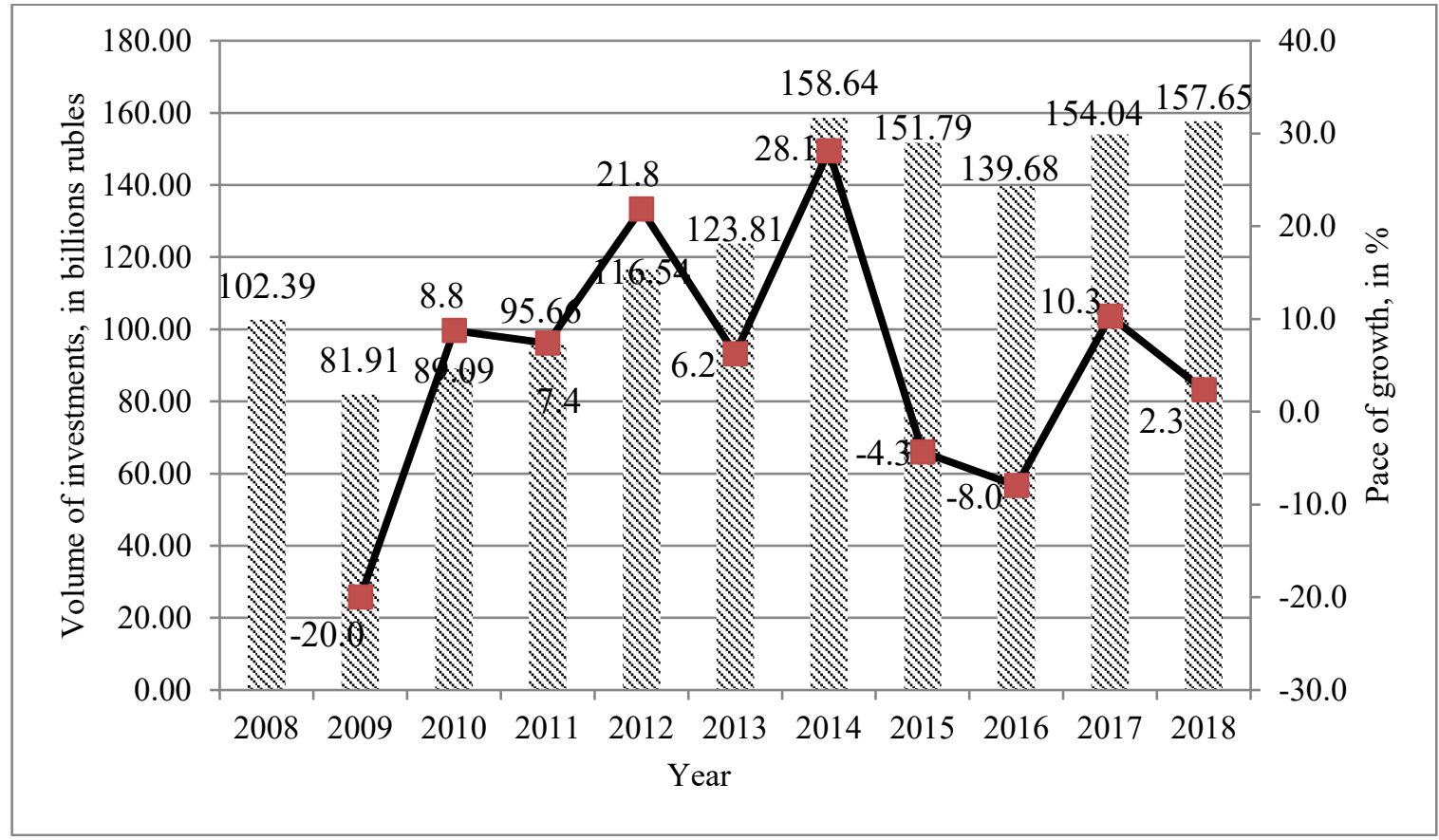

Fig.1. Dynamics and growth rate of green investments in the Russian Federation for 2008-2018 Source: Own results based on Federal State Statistics Service (2019b)

It is also important to note that Russia is characterized by a high share of green investments in manufacturing (40.4\% in 2007 and $42.85 \%$ in 2017 ) and mining (27.52\% in 2007 and $36,47 \%$ in 2017). It can be 
concluded that the creation of an environmentally friendly industry is a priority, therefore, in these sectors of the economy, the process of greening the economy is as intense as possible (Figure 2).

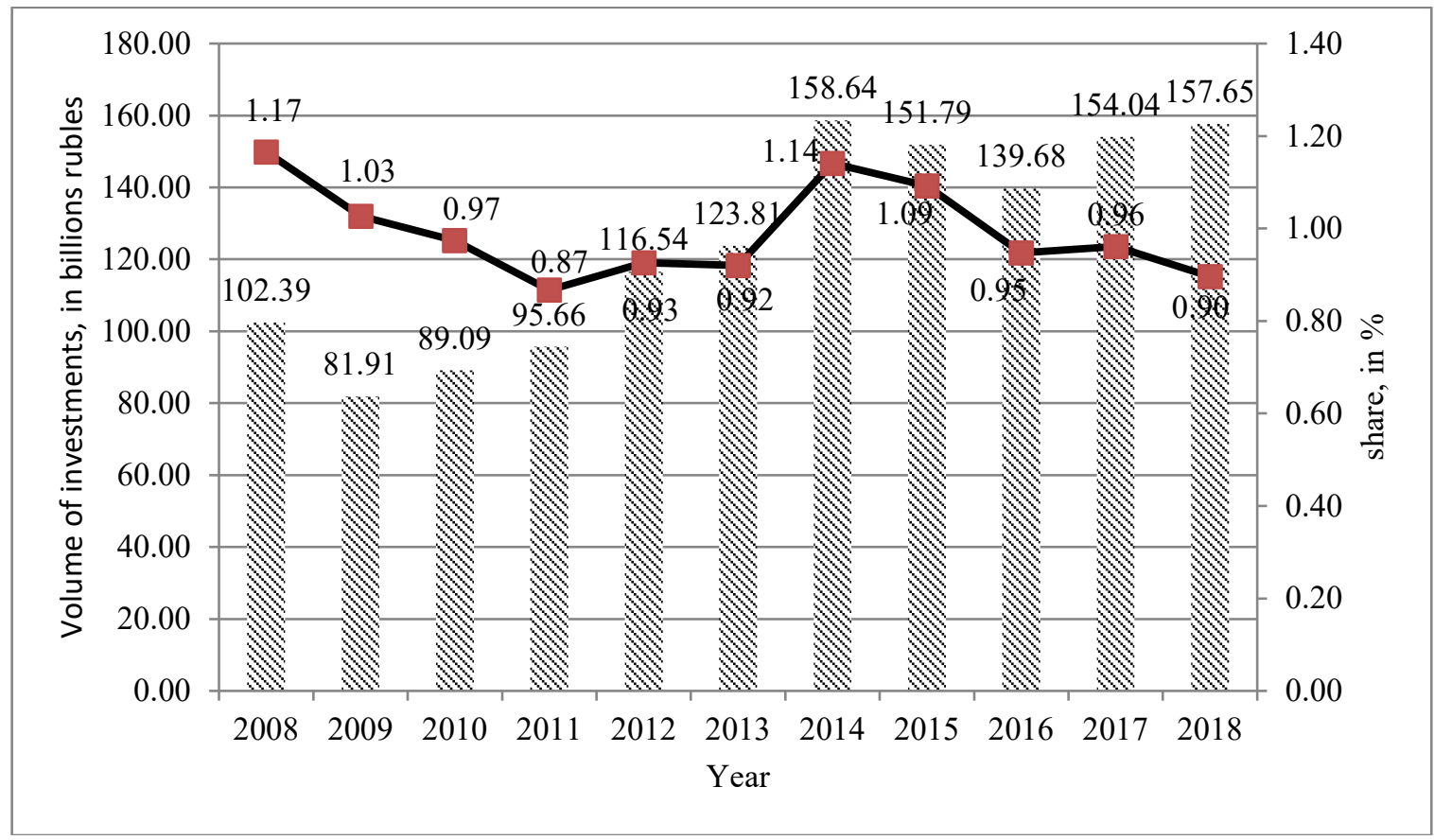

Fig.2. Dynamics of the total volume and share of green investments in the total volume of investments in fixed assets for 2008-2018

Source: Own results based on Federal State Statistics Service (2019a)

Table 2 presents data on the industry focus of green investments for 2007 and 2018. It is important to note that for most countries the manufacturing industry is the highest priority area of economic activity (Dmitrieva 2018). In Russia, this trend is also observed - manufacturing industries attract $41.93 \%$ of all green investments. In addition, the third largest industry with the largest influx of "green" investments is mining, which is a characteristic feature of the Russian Federation due to the prevailing export-raw material model of the economy.

Table 2. Sectoral structure of green investments in Russia, in \%

\begin{tabular}{|c|c|c|c|}
\hline No. & Indicator & $\mathbf{2 0 0 7}$ & $\mathbf{2 0 1 8}$ \\
\hline 1 & Agriculture, hunting and forestry & 0,51 & 0,71 \\
\hline 2 & Mining & 27,52 & 15,34 \\
\hline 3 & Manufacturing & 40,40 & 41,93 \\
\hline 4 & $\begin{array}{c}\text { Production and distribution of electricity, gas and } \\
\text { water }\end{array}$ & 26,18 & - \\
\hline 5 & Transport and communication & 2,98 & - \\
\hline 6 & $\begin{array}{c}\text { The provision of other utility, social and personal } \\
\text { services }\end{array}$ & 2,41 & - \\
\hline 7 & $\begin{array}{c}\text { Water supply; water disposal, organization of waste } \\
\text { collection and disposal, pollution elimination } \\
\text { activities }\end{array}$ & - & 28,71 \\
\hline 8 & Transportation and storage & - & 2,34 \\
\hline
\end{tabular}

Source: Own results based on Federal State Statistics Service (2019c)

It is also important to note that during the analyzed period, green investments in agriculture, hunting and forestry grew from 304.3 million rubles to 2.5 billion rubles, which indicates the attractiveness of this sector. This was facilitated, first of all, by the country's orientation to the domestic market of agricultural producers.

The Russian "green" financial sector is now in its infancy, but the experience of developing countries shows that this sector is developing dynamically and is able to speed up the process of environmental modernization of the economy at times. Today in Russia only a few companies are participants in global initiatives in the field of sustainable development and green financing. A good example is the unification of more than 50 participants in the Russian network of the UN Global Compact, including large companies, small and mediumsized businesses, business associations, public organizations and academic institutions from 16 regions of Russia 
(Vnesheconombank, PJSC MMC Norilsk Nickel, PJSC Severstal, JSC RUSAL, PJSC NK Rosneft, PJSC LUKOIL, etc.).

One of the leaders of the Russian financial market in the field of corporate social responsibility and sustainable development along with Sberbank of Russia, Atomenergosbyt and other companies over the past years is Vnesheconombank (VEB), which has significant investments in green investments. Since 2013, Vnesheconombank has been the chairman and leader of the UN global compact network. Today Vnesheconombank is considering a number of projects that are classified as green. These are initiatives in the field of solar and wind energy, utilization of solid municipal waste, and the creation of smart electric grids. Vnesheconombank considers the green direction in its activities as a tool to increase export competitiveness, as a platform for interaction with national and international development institutions. Together with the Bank of Russia, the Moscow Exchange and market participants, special tools for green financing are being developed.

\section{Conclusions}

Overall, Green Finance has become a key trend in the last decade. The experience of other countries shows that transformations within the framework of the "green" economy can further increase the gross domestic product, create new jobs, create new industries and services. To form a system of "green" financing in Russia, a wide involvement of all economic entities in this process is necessary. A key component of such a process is the adjustment by the authorities of the current model of economic development with the mandatory participation of all interested parties.

Today, the key problems hindering the development of the green finance market in Russia are such as the lack of a legislative framework for regulating green finance, a system of state support for attracting green investments, a verification system for green securities, and a reduction in government funding for green investments. .

In order to achieve the goal of creating a green finance market in Russia, it is necessary to apply a systematic and integrated approach that will remove all obstacles and mobilize financial resources to ensure economic sustainability.

\section{References}

Andreeva EI (2016) G20: cooperation for global economic growth. Finance 9:8-12

Andreeva LY (2017) Institutions and instruments of "green financing": risks and opportunities for sustainable development of the Russian economy Forestry Magazine 2:205-214

Cieslik A, Michalek J, Mycielski J (2016) Globalization, international trade, and human development: a case of Central and Eastern Europe. Czech Journal of Social Sciences, Business and Economics 5(2):6-15. doi: 10.24984/cjssbe.2016.5.2.1

Central Bank of Russia (2018) Green finance: an agenda for Russia. A diagnostic note. Expert advice on the longterm investment market under the Bank of Russia, $64 \mathrm{p}$.

Dmitrieva TE (2018) Ecologization of the bioresource economy of the northern region. Economic and social changes: facts, trends, forecast 11(4):160-172

Dual Citizen (2019) Global Green Economy Index. https://dualcitizeninc.com/global-green-economy-index Accessed: on 28 November 2019

EBRD (2019) Green Economy Transition. https:/www.ebrd.com/news/publications/special-reports/greeneconomy-transition.html. Accessed 29 November 2019

Federal State $\quad$ Statistics $\quad$ Service $\quad$ (2019a) Investments. http://www.gks.ru/wps/wcm/connect/rosstat_main/rosstat/ru/statistics/enterprise/investment/nonfinancial. Accessed on 29 November 2019

Federal State Statistics Service (2019b) Publication catalog "Investments in Russia". http:/www.gks.ru/wps/wcm/connect/rosstat_main/rosstat/ru/statistics/publications/catalog/doc_1136971099875. Accessed 28 November 2019

Federal State Statistics Service (2019c) Publication catalog "Environmental Protection in Russia". http://www.gks.ru/wps/wcm/connect/rosstat_main/rosstat/ru/statistics/publications/catalog/doc_1139919459344. Accessed 28 November 2019 
Federal State Statistics Service (2019d) Catalog of publications "Russia and the World". http://www.gks.ru/wps/wcm/connect/rosstat_main/rosstat/ru/statistics/publications/catalog/doc_1139821848594. Accessed 22 November 2019

French G (2017) "Green bonds": the era of maturity. https:/www.about.hsbc.ru/-/media/.../170925-green-bondscoming-of-age-ru.pdf. Accessed on 20 November 2019

Hoop GYu, Tarkhanova EA (2019) Transition to a green economy: development of the concept and experience of foreign countries. Intercultural dialogue and cooperation between the EU and Russia: experience in implementing projects of Jean Monnet at the Nizhnevartovsk State University. In Kozlova O (ed.) Proceedings of the International Scientific and Practical Conference, Nizhnevartovsk, April 15-19, 2019, Part 2: New challenges of the green economy: practice and experience of the countries of the European Union and Russia, Nizhnevartovsk: Nizhnevartovsk State University, pp. 98-101

Lisin E, Shuvalova D, Volkova I, Strielkowski W (2018) Sustainable development of regional power systems and the consumption of electric energy. Sustainability 10(4):1111. doi: 10.3390/su10041111

Lisin E, Rogalev A, Strielkowski W, Komarov I (2015) Sustainable modernization of the Russian power utilities industry. Sustainability 7(9):11378-11400. doi: 10.3390/su70911378

Nozdryva RB (2018) "Green Bonds" as a modern tool for environmental financing in the business of Japan. Financial Business 3:45-49

Panda P (2017) Green Bond: A Socially Responsible Investment Instrumentю Research Bulletin 43(1):97-113

Pearce D (2019) Blueprint for a Green Economy, Earthscan Publications Limited. http://www.environmentandsociety.org/files/key_docs/pearce_1_1.pdf. Accessed on 17 November 2019

Rakov ID (2017) Mechanisms for supporting the financing of green projects: the experience of countries. Actual Problems of Economics and Law 11(2):67-82

Shevchenko AA (2018) Instruments for financing green investments. http://portal.tsuab.ru/ScienceWork/2018/Konf_V_MNPK_2018/377_Konf_V_MNPK_2018.pdf. Accessed on 11 December 2019

Tarkhanova EA (2018) Innovations and sustainability in the financial and banking sectors. Terra Economicus 16(2):75-82. doi: 10.23683/2073-6606-2018-16-2-75-82

UNCTAD (2019) Trade and the green economy. https://wedocs.unep.org/trade_GE_handbook_RU.pdf. Accessed on 26 November 2019

United Nations (2019) United Nations Environment Program. https://www.un.org/ru/ga/unep. Accessed on 28 November 2019

World Bank (2018) Russian green finance: unlocking opportunities for green investments. An analytical note. http://documents.worldbank.org/curated/en/103531540924946297/pdf/131516-PN-P168296-P164837-PUBLICGreen-finance-Note.pdf Accessed 15 December 2019 